\title{
Cryoprotectants in the Technology for the Production of Frozen Bakery Products
}

\author{
Nadezhda V. Kenijz' ${ }^{1}$ Anton A. Nesterenko ${ }^{*}$, Maya S. Zayats ${ }^{1}$ \\ ${ }^{1}$ Kuban State Agrarian University, Krasnodar, Russian Federation, *e-mail: nesterenko-aa@mail.ru
}

\begin{tabular}{l|l} 
Keywords: & Abstract \\
cryoprotectors; & $\begin{array}{l}\text { Recently, Russia has actively developed production of semi-finished and semi-finished } \\
\text { products with the possibility of bringing it to readiness. During the freezing process of ice }\end{array}$ \\
pectin; & $\begin{array}{l}\text { crystals that damage the yeast cell and reduce the strength of the dough. A man uses cryo- } \\
\text { yeast; }\end{array}$ \\
$\begin{array}{l}\text { protectants to reduce the amount of ice. The paper presents the study results of the func- } \\
\text { products; } \\
\text { bread }\end{array}$ & $\begin{array}{l}\text { tional, technological and rheological properties of the dough blank using cryoprotectants, } \\
\text { and the influence of cryoprotectants on the structure of frozen semi-finished products. For } \\
\text { the first time, an NMR analyzer was used to analyze the water-absorbing ability of flour. }\end{array}$
\end{tabular}

\section{Криопротекторы в технологии производства замороженных хлебобулочных изделий}

\section{Н.В. Кенийз ${ }^{1}$, А.А. Нестеренко ${ }^{1 *}$, М.С. Заяч ${ }^{1}$}

${ }^{1}$ Кубанский государственный аграрный университет им. И.Т. Трубилина, г. Краснодар, Российская Федерация *e-mail:a.v.diachkova@urfu.ru

Ключевые слова:
криопротектор;
пектин;
дрожж;
полуфабрикаты
из теста;
хлеб

Для цитирования: Кенийз Н.В., Нестеренко А.А., Заяц М.С. Криопротекторы в технологии производства замороженных хлебобулочных изделий //Индустрия пuтания/Food Industry. 2019. T. 4, № 4. C. 23-29. D0I 10.29141/2500-1922-2019-4-4-3

Дата поступления статьи: 23 сентября 2019 г.

\section{Introduction}

In order to provide the population with high-quality bakery products, it is necessary to develop competitive, highly efficient technologies for the production of bakery products based on frozen convenience foods. The technology of freezing semi-finished products allows you to have their stock replenished in a wide range, to ensure the quality and safety of finished products; reduce the share of manual labor; use small rooms and a minimum set of equipment for mini-bakeries. Of all the technologies, the most widely used technology is the freezing of dough semi-finished products after 
molding, in which after refrigerated storage the dough semi-finished products are thawed, settled and baked. However, the stages of freezing, thawing and proofing reduce gas formation and survival of yeast cells, impair the rheological properties of the dough and the quality of the products.

Therefore, it is important to improve this technology for the production of bakery products from quick-frozen dough semi-finished products [1. Pp. 23; 2. Pp. 50].

In Russia, new technologies are being intensively developed, based on the freezing of semi-finished bakery production, they are most likely to be used in small enterprises and the HoReCa segment (hotels, restaurants, cafes), since these technologies are more flexible than traditional ones, which is very convenient for small enterprises [4. Pp. 24; 5. Pp. 24].

The production of frozen semi-finished products allows you to control the safety and quality of products, to respond quickly to market changes, the cost of transporting finished products is significantly reduced, it is possible to increase the network of bakeries, in places of sale, due to the possibility of using the minimum amount of equipment [3. Pp. 57; 7. Pp. 218].

However, there are a number of reasons that impede the rapid introduction of new progressive technology in the industry.

During the freezing of the dough semi-finished products, denaturation and aggregation of proteins occurs, causing the loss of functional properties, yeast cells die due to the formation of ice crystals. It should also be noted that during freezing, dough, dough pieces, there is a loss of moisture. Therefore, the freezing of dough, dough pieces in the technology of bread and bakery products, at the production carried out with the addition of various cryoprotectants [6. Pp. 14; 8. Pp. 48].

The use of various cryoprotectants, for example, enzyme preparations with glucoamylase and hemicellulase, enzyme-modified lecithin "Solek-K-EML" or the use of whipped frozen semi-finished products is known.

The addition of cryoprotectants during freezing can reduce or prevent protein denaturation. The confirmation of the mechanism of cryoprotection by low molecular weight carbohydrates is served by studies of J. Park and T. C Lanier. They proved that the addition of sugars (lactose and glucose) to an aqueous solution of proteins led to an undesirable spontaneous change - stabilization of the solution in isolation from the surface of the hydrated protein [9. Pp. 324]. Among the substances with the property of water-holding capacity, of interest is pectin, which is used in the food industry in the confectionery industry as a gelling agent. Given the complex of positive properties of pectin, it was decided to use it for a new purpose, as a cryoprotectant in the production of frozen semi-finished bakery production [10. Pp. 7 ; 11. Pp. 1562].

The purpose of this work was the development of scientific and practical recommendations on the technology of bread from frozen semi-finished products by studying the patterns of change in the rheological properties of dough, biochemical processes of semi-finished products.

\section{Materials and Methods}

Microbiological research methods for the evaluation of semi-finished products used generally accepted in Russia. The physical and rheological properties of the dough were determined in accordance with the methods of GOST R 51404-99 and GOST R 51415-99. The study of the water absorption capacity of flour mixed with a cryoprotectant on an AMB$1006 \mathrm{M}$ NMR analyzer was conducted for the first time. Improved methods for determining the water absorption capacity and water-binding capacity, applied to semi-finished bakery production. According to the selected method, weighed $10 \mathrm{~g}$ (flour, yeast, salt, cryoprotector) and $6.5 \mathrm{~g}$ of water in a test tube are mixed. Next, the tube is placed in the device and conduct research.

The analyzer includes a personal computer and a semi-automatic weighing device. The analyzer implements the mode of automatic correction of measurement results, depending on changes in the parameters of the external environment and the mode of semi-automatic calibration according to standard samples. The analyzer's operation is controlled and the measurement results are processed using a special program adapted to the Windows XP, Windows 7 operating system. A database of all analyzes with necessary comments and analyzer operation modes is created in the computer's memory. It is possible to connect the analyzer to the computer network of the enterprise. (Register number 01-31005 dated March 18, 2010).

Verification of analyzers AMV-1006M, carried out according to GOST R 8.582-2001 (GOST 8.597-2010) "GSI. NMR analyzers of the oil content and moisture of agricultural materials. Method of verification.

The measurement procedure was approved in the rank of standards GOST R 8.620-2006 (GOST 8.5962010) "GSI. Oilseeds and their products. Methods for the measurement of oil and moisture by the method of pulsed nuclear magnetic resonance".

\section{Results and Discussion}

The effect of various cryoprotectors on the rheology of the dough for semi-finished products. For dough subject to freezing, three fundamental factors are important: gas formation, gas hold- 
ing, rheological properties of the dough, because when exposed to low temperatures, gas formation decreases, gas holding capacity decreases and the rheological properties of the dough decrease. To correct and preserve the optimal data of the listed factors, cryoprotectors are used - substances whose properties are moisture retention [11. Pp. 1561].

At the first stage of research, we conducted work on studying the effect of various cryoprotectors on the rheology of dough. The rheological properties of the dough using cryoprotectants were studied using a farinograph and alveograph on devices. In the experiment on the effect of cryoprotectants (pectin, sorbitol, fructose) on the physical properties of the dough, variants with the introduction of cryoprotectants in dosages of $0.5 ; 1.0 ; 1.5 ; 2,0 \%$ to the mass of flour. The control served as a sample without making additives. The obtained experimental data are presented in Figures 1, 2, 3.
Analysis of the data showed that the use of pectin in kneading dough leads to an increase in WAC (water absorption capacity) of dough in all variants of experiments in comparison with the control. It should be noted that the addition of pectin increases the kneading time of the dough. The formation time and stability of the dough increased at the same time from 8.5 minutes at the control, to 10 minutes when pectin was added to the dough at a dosage of $1.5 \%$. Valorimetric evaluation in all variants with pectin was higher compared with control at 8 e. When adding sorbitol and fructose, in the same dosages, the indicators of the rheological properties of the dough were lower in comparison with the variant where pectin was added during kneading the dough at 8 and 14 e. C. respectively. Analysis of the results obtained on the device farinograph, led to the conclusion that WAC in the variants with the addition of pectin increases due

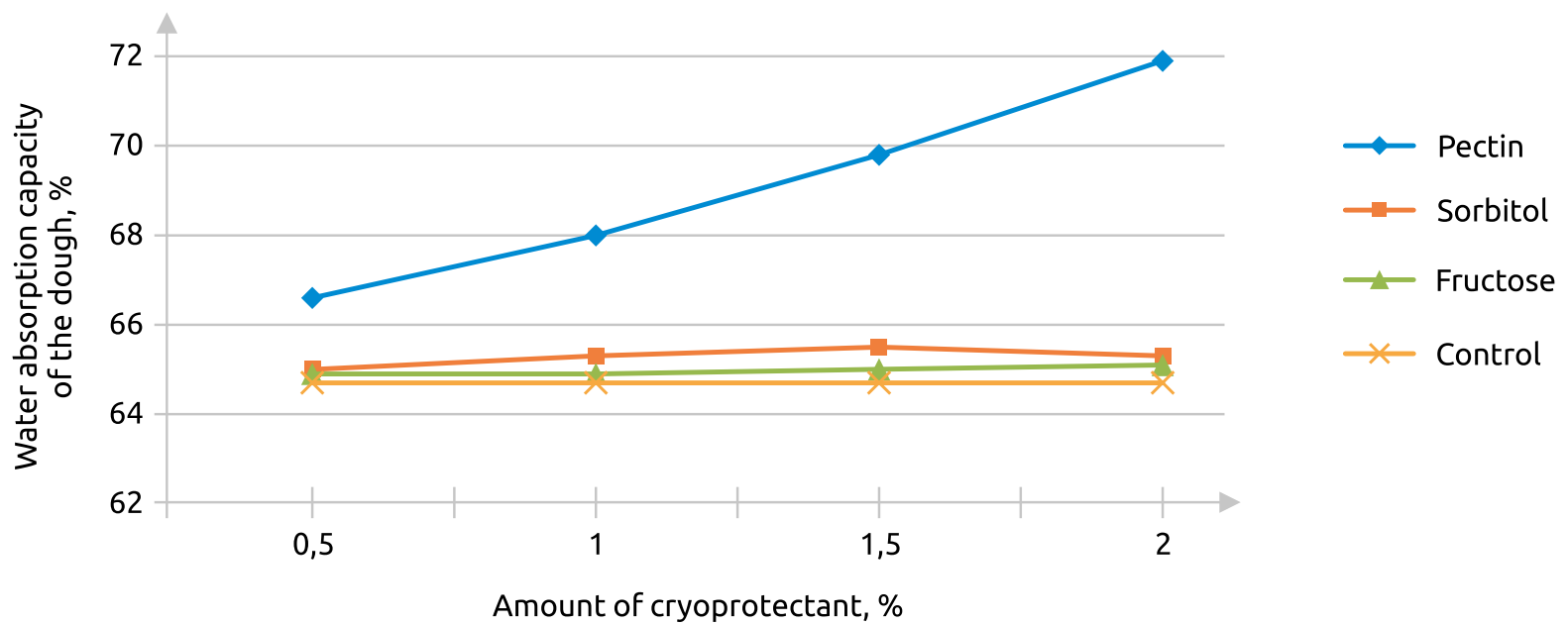

Fig. 1. Change in water absorption capacity of the dough with addition of cryoprotectants Pис. 1. Изменение водопоглощающей способности теста с добавлением криопротекторов

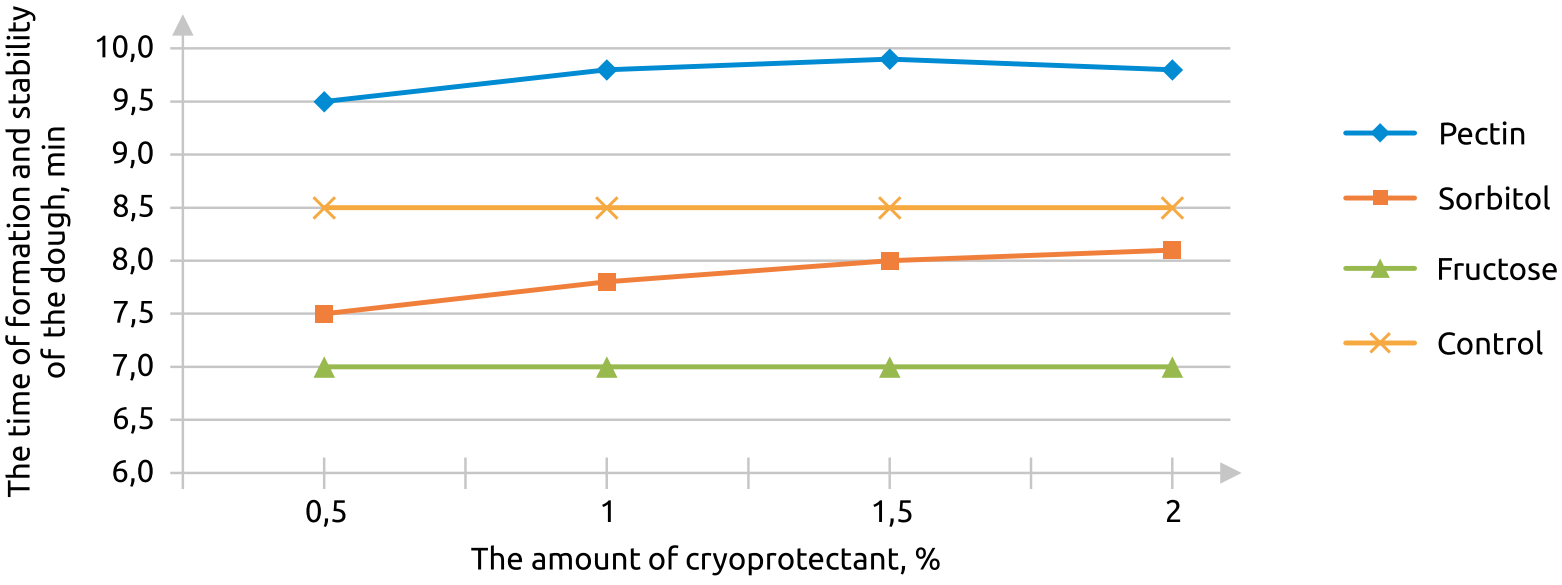

Fig. 2. Change of formation time and stability of the dough with addition of cryoprotectants Pис. 2. Изменение времени подъема и стабильности теста при добавлением криопротекторов 


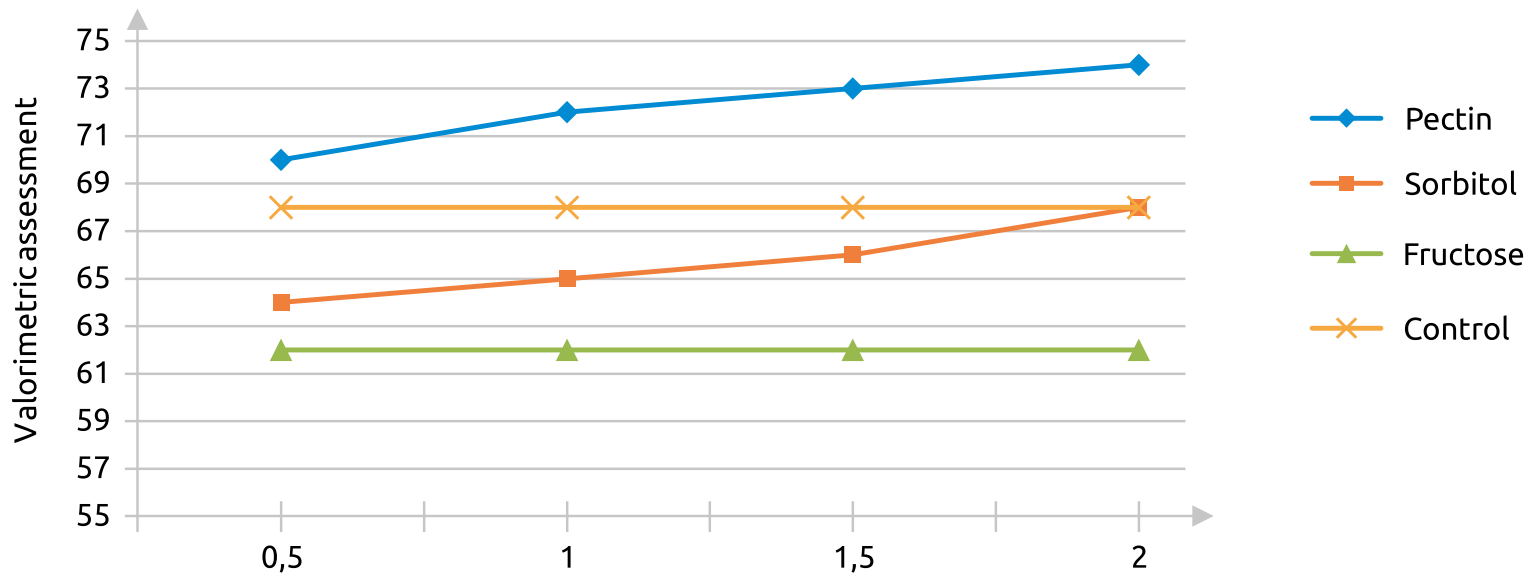

The amount of cryoprotectant, \%

Fig. 3. Changes in the valorimetric assessment of the dough with addition of cryoprotectants Рис. 3. Изменение калориметрической оценки теста при добавлении криопротекторов

to the ability of the pectin carboxyl groups to retain water, which is a positive factor when freezing dough pieces. The improvement of the structural and mechanical properties of the dough is associated with the strengthening of gluten-free scaffolds, due to the interaction of hydroxyl and free carboxyl groups with the amino groups of gluten proteins, due to conformational changes in the protein molecule, resulting in a more "dense package", as well as due to the ability to approximate methoxylated carboxyl groups in the aquatic environment, with the formation of polymer chains of pectin, which is of no small importance in the technology of frozen semi-finished products [11. Pp. 1564].
The main indicator of the baking properties of flour is the "flour power" indicator, which was determined on the alveograph. In the experiment, previously used dosages of cryoprotectants were used. The data obtained are presented in table 1.

Studies on the study of pectin as a cryoprotectant show that it exceeds the cryoprotectants currently used, such as fructose, sorbitol in terms of formation time and dough stability. In the case of adding pectin, the dilution of the dough occurred $1.5 \mathrm{~min}$ utes later, compared with sorbitol at dosages of 1.0; $1.5 \%$, and with the addition of fructose, in the same dosages for 2 and 3 minutes. Flour strength was also higher when pectin was added at 18 and $17 \mathrm{u}$. a.

Table 1. Changes in the rheological parameters of the dough when making cryoprotectants Таблица 1. Объекты исследования

Indicator

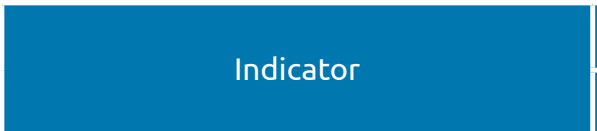

Power of the flour, u. a.

Maximum overpressure, $\mathrm{mm}$

Ratio of resilience to elasticity $(R / E)$

Power of the flour, u. a.

Maximum overpressure, $\mathrm{mm}$

Ratio of resilience to elasticity (R / E)

Power of the flour, u. a.

Maximum overpressure, $\mathrm{mm}$

Ratio of resilience to elasticity (R / E)

The value of the dough when making cryopro-tectants in the dosage, \%

Control (0)

\section{5}

1.0

1.5

Pectin
227

71

0.70
235

70

0.7
Fructose 
in comparison with sorbitol and 20, 22 u. a. when adding fructose. Improving the rheology of the dough when adding pectin during kneading occurs because pectins form a strong frame, due to the convergence of hydrophobic methoxyl groups in the aquatic environment, and free carboxyl groups dissociate into ions that interact on the protein surface with $-\mathrm{NH} 3+$ groups, since pectins represent a surface-active compounds and thereby improve the structural and mechanical properties of the dough.

Since the dough is subject to freezing, the rheological properties are important factors, the data obtained provide the basis for further research on its effect on the quality of frozen semi-finished products.

Influence of cryoprotectants on the structure of frozen convenience foods. Using the method of microscopy, it was found that the cryoprotector affects the binding capacity of water in the cell, in connection with which the dough without the addition of pectin and with pectin has different physical properties (Figure 4).

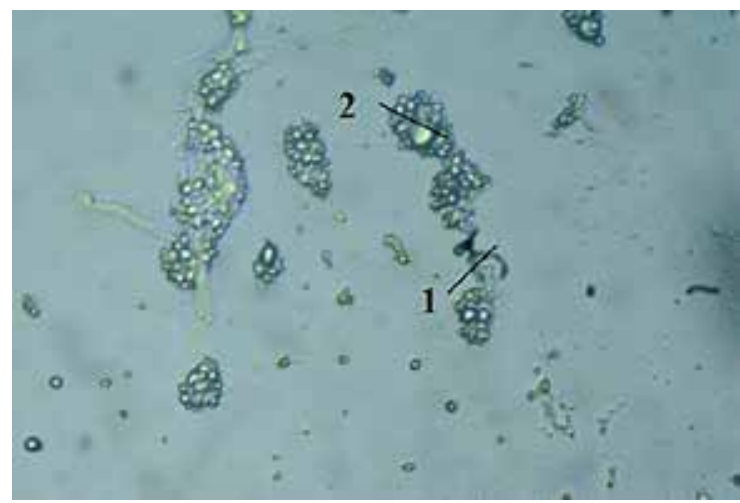

a)

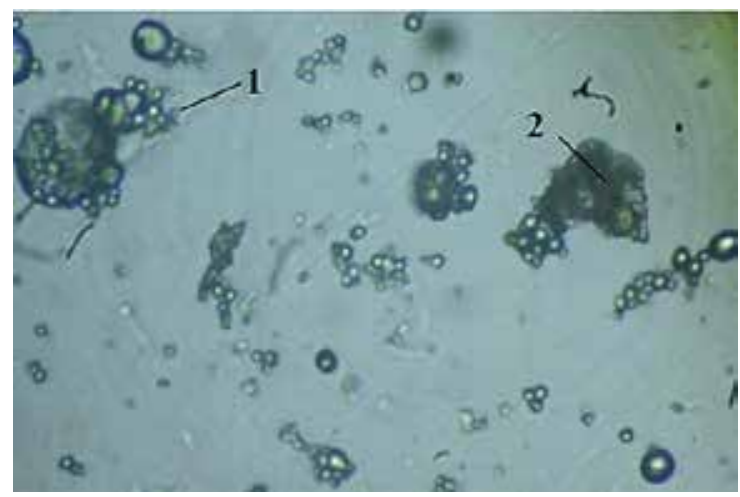

b)

Fig. 4. Micrographs of frozen yeast dough:

a) without the introduction of a cryoprotectant;

b) with the addition of pectin

(1 - protein, 2 - starch grains)

Puc. 4. Микрография замороженного дрожжевого mecma:

а) без добавления криопротектора;

6) с добавлением пектина

(1 - белок, 2 - крахмальные зерна)
In the sample without the addition of a cryoprotectant, the polymer chains of starch and protein are a compressed compacted structure. When pectin is added while kneading the dough, an increase in the polymer chains due to the formation of protein-polysaccharide complexes is clearly seen on the sample cut. In the works of N. V. Kenyiz [3], it is noted that the glass transition of a polymer chain is influenced by the number and size of replacement groups (i.e., side chains). When pectin is attached to the polymer chains of protein and starch, its side chains act as a plasticizer and lower the glass transition temperature. The obtained results allow us to conclude that the addition of pectin leads to the formation of protein-polysaccharide complexes, allowing to reduce the glass transition temperature.

From the literature it is known that an increase in the molecular weight of the polymer also reduces the glass transition temperature. In our studies, the addition of pectin increases the molecular weight of polymers and this is also a positive factor when freezing dough semi-finished products.

Thus, it can be concluded that adding pectin during kneading dough intended for freezing reduces the glass transition temperature, by increasing the molecular weight of the polymer, forming protein-polysaccharide complexes, in addition, the pectin side chains in the branched structure of the polymer act as plasticizer and additionally lower the glass transition temperature.

Effect of freezing rate on the structure of ice crystals. In the work of L. J. Hayes, the freezing rate is determined relative to the speed of the freezing front. This approach is also adopted in the «Red Book» of the International Institute of Refrigeration.

The speed of freezing determines the type, size and distribution of the formed ice, which can be represented by extra-and intracellular ice, tree-like or sphere-like ice (in quick frozen aqueous solutions), sometimes partially limited by the food matrix. By using very high cooling rates, ice formation can be completely avoided, and instead vitrification can be achieved, to a glassy state.

An overview of the processes of ice crystallization in food products is presented in the works of the authors C. A. Angell, J.V. Blanshard. Due to the difficulties in interpreting the results of measuring the proportion of ice formed in complex food matrices, most of the studies were carried out on model systems that were aqueous solutions [6. Pp. 14].

Larger ice crystals are formed by slow freezing. Smaller crystals - at fast. Which crystals (large or small) are more preferable depends on the purpose of freezing - in the production of ice cream, ice crystals should be as small as possible, since the finished product is more homogeneous and the texture is smoother. However, when freezing liquid products, 
it is more convenient to separate large ice crystals from the concentrate. For freeze-drying of a food product, the formation of a small number of large crystals is desirable, this allows the subsequent sublimation process to be accelerated.

At the initial stage of the freezing process, the water present in the food product migrates and joins the growing ice crystals. With rapid freezing, plant or animal tissue, water does not penetrate through the cell membrane, and small uniformly distributed ice crystals form inside the cell.

The speed of freezing food in industrial environments is usually too low for the formation of intracellular ice. During slow freezing of food products, large ice crystals are formed, which fill the intercellular space and cause dehydration of cells. Ice crystals divide cells or tissue fibers, despite the fact that small ice crystals form in quickly frozen food products, as a result of a process called recrystallization or ripening of Ostwald, they may become larger over time. When storing frozen food, recrystallization occurs due to the fact that larger crys- tals are thermodynamically more stable, due to the relatively small surface energy. Temperature gradients enhance recrystallization during freezing or thawing of foods. Temperature fluctuations, during long-term cold storage, during transportation and storage in household refrigerators (the temperature of the defrosting mode in a home refrigerator with the frost-free option can rise to almost $0{ }^{\circ} \mathrm{C}$ ), recrystallization also increases.

\section{Conclusion}

Scientifically substantiated and given practical recommendations on the use of pectin as a cryoprotectant in the technology of bread from frozen semi-finished products. It was found on the NMR analyzer that when kneading dough with pectin at a dosage of $1.5 \%$ to the flour mass, intensive water binding occurs after kneading the dough, which is confirmed by the absence of weakly bound moisture in the sample with pectin, which forms crystals with decreasing temperature.

\section{Bibliography}

1. Arsenjeva, L.Yu.; Gubenya, V.A. Hlebobulochnye Izdeliya, Obogashchennye Zhelezom [Bakery Products Enriched with Iron]. Vestnik Almatinskogo Tekhnologicheskogo Universiteta. 2015. № 1. Pp. 21-28.

2. Vershinina, O.L.; Roslyakov, Yu.F.; Gonchar, V.V. Hlebobulochnye Izdeliya, Obogashchennye Organicheskim Jodom [Bakery Products Enriched with Organic lodine]. Hleboprodukty. 2016. № 3. Pp. 50-51.

3. Chernyh, V.Ya.; Berdyshnikova, O.N.; Zhirnova, E.V.; Mitin, V.Yu. Vliyanie Dispersnosti Pshenichnoj Muki na ee Tekhnologicheskie Svojstva i Parametry Zamesa Testa [Dispersion Influence of Wheat Flour on its Technological Properties and Parameters of Dough Kneading]. Hleboprodukty. 2015. № 7. Pp. 56-58.

4. Dojche, B. Tekhnologiya Glubokogo Zamorazhivaniya: Specialnye Hlebopekarnye Koncentraty Optimiziruyut Kachestvo Hlebobulochnyh Izdelij [Deep Freezing Technology: Special Baking Concentrates Optimize Bakery Products Quality]. Hleboprodukty. 2011. № 09. Pp. 23-27.

5. Lapteva, N.K.; Mitkinyh, L.V. Novye Hlebobulochnye Izdeliya s Ispolzovaniem Rzhanogo Syrya [New Bakery Products with Rye Raw Materials Use]. Agrarnaya Nauka Evro-Severo-Vostoka. 2016. № 3 (53). Pp. 23-26.

6. Matveeva, I. Biotekhnologicheskie Resheniya dlya Proizvodstva Zamorozhennyh Polufabrikatov i Hlebobulochnyh Izdelij [Biotechnological Solutions for the Production of Frozen Semi-Finished Products and Bakery Products]. Hleboprodukty. 2011. № 9. Pp.12-17.

7. Nilova, L.P.; Pilipenko, T.V., Malyutenkova, S.M. Obogashchennye Hlebobulochnye Izdeliya kak Istochniki Vodorastvorimyh Antiok sidantov [Enriched Bakery Products as Sources for Water-Soluble Antioxidants]. V Mire nauchnyh otkrytij. 2015. № 5 (65). Pp. 214-227.

\section{Библиографический список}

1. Арсеньева Л.Ю., Губеня В.А. Хлебобулочные изделия, обога щенные железом // Вестник Алматинского технологического университета. 2015. № 1. С. 21-28.

2. Вершинина О.Л., Росляков Ю.Ф., Гончар В.В. Хлебобулочные изделия, обогащенные органическим йодом // Хлебопродукты. 2016. № 3. C. 50-51.

3. Черных В.Я., Бердышникова О.Н., Жирнова Е.В., Митин В.Ю. Влияние дисперсности пшеничной муки на ее технологические свойства и параметры замеса теста // Хлебопродукты. 2015. № 7. С. 56-58.

4. Дойче Б. Технология глубокого замораживания: специальные хлебопекарные концентраты оптимизируют качество хлебобу лочных изделий // Хлебопродукты. 2011. № 09. С. 23-27.

5. Лаптева Н.К., Митькиных Л.В. Новые хлебобулочные изделия с использованием ржаного сырья // Аграрная наука Евро-Северо-Востока. 2016. № 3 (53). С. 23-26.

6. Матвеева И. Биотехнологические решения для производства замороженных полуфабрикатов и хлебобулочных изделий // Хлебопродукты. 2011. № 9. С.12-17.

7. Нилова Л.П., Пилипенко Т.В., Малютенкова С.М. Обогащенные хлебобулочные изделия как источники водорастворимых антиоксидантов // В мире научных открытий. 2015. № 5 (65). C. 214-227.

8. Дубцов Г.Г., Цалоева М.Р., Кусова И.У., Богданов А.Р. Функциональные хлебобулочные изделия для людей с высокой физической активностью // Хлебопродукты. 2015. № 4. С. 48-49.

9. Романов А.С., Ильина О.А., Иунихина В.С., Краус С.В. Хлеб и хлебобулочные изделия. Сырье, технологии, ассортимент: учеб. пособ. М.: ДеЛи плюс, 2016. 635 с. 
8. Dubcov, G.G.; Caloeva, M.R.; Kusova, I.U.; Bogdanov, A.R. Funkcionalnye Hlebobulochnye Izdeliya dlya Lyudej s Vysokoj Fizicheskoj Aktivnostyu [Functional Bakery Products for People with High Physical Activity]. Hleboprodukty. 2015. № 4. Pp. 48-49.

9. Romanov, A.S.; Iljina, O.A.; lunihina, V.S.; Kraus, S.V. Hleb i Hlebobulochnye Izdeliya. Syrje, Tekhnologii, Assortiment [Bread and Bakery Products. Raw Materials, Technologies, Assortment]: Ucheb. Posob. M.: Deli plyus, 2016. P. 635.

10. Hlebobulochnye Izdeliya v Profilaktike Zhelezodeficitnoj Anemii [Bakery Products in the Prevention of Iron Deficiency Anemia]. Dubcov, G.G.; Kusova, I.U.; Dubcova, G.N. [i dr.]. Voprosy Dietologii. 2019. T. 9, № 1. Pp. 5-10.

11. Issledovanie Vliyaniya Krioprotektorov na Sohranenie Tekhnologicheskih Svojstv Zamorozhennyh Testovyh Polufabrikatov [Research of Cryoprotectors Influence on the Technological Properties Preservation of the Frozen Semi-Finished Products under the Research]. Kenijz, N.V.; Nesterenko, A.A.; Omarov, R.S.; Konik, N.V.; Rysmuhambetova, G.E. Nauchno-Issledovatelskij Zhurnal Farmacevticheskih, Biologicheskih i Himicheskih Nauk. 2019 god. № 10 (1). Rr. 1559-1566.
10. Хлебобулочные изделия в профилактике железодефицитной анемии / Г.Г. Дубцов, И.У. Кусова, Г.Н. Дубцова [и др.] // Вопросы диетологии. 2019. Т. 9, № 1. С. 5-10.

11. Study of the influence of cryoprotectants on the preservation of the technological properties of frozen test semi-finished products / N.V. Kenijz, A.A. Nesterenko, R.S. Omarov, N.V. Konik, G.E. Rysmukhambetova // Research Journal of Pharmaceutical, Biological and Chemical Sciences. 2019. № 10(1). Pp. 1559-1566.

\section{Информация 06 авторах / Information about Authors}

\section{Kenijz, Nadezhda Viktorovna}

Кенийз

Надежда Викторовна

тел./Phone: +7 (861) 221-59-42

E-mail:keniz@bk.ru
Candidate of Technical Science, Associate Professor of the Department of Technology for Storage and Crop Products Processing Kuban State Agrarian University 350044, Russian Federation, Krasnodar, Kalinina St., 13

Кандидат технических наук, доцент кафедры технологии хранения и переработки растениеводческой продукции

Кубанский государственный аграрный университет им. И.Т. Трубилина 350044, Российская Федерация, г. Краснодар, ул. Калинина, 13

ORCID: https://orcid.org/0000-0002-5003-9339

Candidate of Technical Science, Associate Professor

Associate Professor of the Department of Technology for Storage and Crop Products Processing Kuban State Agrarian University

350044, Russian Federation, Krasnodar, Kalinina St., 13

Кандидат технических наук, доцент, доцент кафедры технологии хранения и переработки животноводческой продукции Кубанский государственный аграрный университет им. И.Т. Трубилина 350044, Российская Федерация, г. Краснодар, ул. Калинина, 13

ORCID: https://orcid.org/0000-0003-1780-9466

Student

Kuban State Agrarian University

350044, Russian Federation, Krasnodar, Kalinina St., 13

Студент

Кубанский государственный аграрный университет им. И.Т. Трубилина 350044, Российская Федерация, г. Краснодар, ул. Калинина, 13

ORCID: https://orcid.org/0000-0002-5003-9339 